Original Research Paper

\title{
Effect of Microwave Pretreatment on BMP of Decanter Cake from Palm Oil Mill Factory
}

\author{
Thaniya Kaosol and Worawuth Rungarunanotai \\ Environmental Engineering Program, Department of Civil Engineering, \\ Faculty of Engineering, Prince of Songkla University, Songkhla, Thailand
}

Article history

Received: 17-05-2015

Revised: 24-02-2016

Accepted: 23-05-2016

Corresponding Author:

Thaniya Kaosol

Environmental Engineering

Program, Department of Civil

Engineering, Faculty of

Engineering, Prince of Songkla

University, Songkhla, Thailand

Email: thaniya.k@psu.ac.th

\begin{abstract}
Anaerobic digestion is an effective method for treating decanter cake in the biogas production. Decanter cake usage is limited by its slow fiber degradation for anaerobic digestion process. The aim of this study is to study the possibility of using microwave pretreatment to enhance decanter cake digestibility. The power and heating time are the parameters that influence the biogas production and methane yield. The Biochemical Methane Potential (BMP) tests are used in this study to find the optimization setting of a microwave pretreatment for decanter cake solubilization and anaerobic digestibility. The results show that the microwave pretreatment provides a better performance in terms of COD solubilization and anaerobic digestibility. The increasing power and heating time can improve the biogas production and methane yield for microwave pretreated decanter cake under anaerobic digestion process. Finally, the optimum power and heating time used in the microwave pretreatment, found in this study, is 160 watts and 8 min for methane yield under the anaerobic digestion process. The highest methane yield is $309.9 \mathrm{~mL} \mathrm{CH}_{4} / \mathrm{g}$ COD removed. The microwave pretreated decanter cake at 160 watts of power and 8 min of heating time can improve the methane yield with an improvement of $24.6 \%$ in comparison with the non-microwave pretreated decanter cake. It can be concluded that the microwave pretreatment of decanter cake from palm oil mill factory could be the rapid and environmental method for biogas production enhancement.
\end{abstract}

Keywords: Decanter Cake, Microwave, Pretreatment, BMP, Anaerobic Digestion

\section{Introduction}

Anaerobic digestion of organic wastes has been established due to the increasing investments in renewable energy production and in greenhouse gas emission reduction. Especially in the southern of Thailand, many biogas plants have been established by combining wastes from agriculture, agro-industry, industry and households for biogas. Fertilizer production is another product from such wastes which are recycled back on farmland and forestland. The anaerobic digestion is an oldest technology for organic waste stabilization (Lier et al., 2001; Malakahmad et al., 2012; 2013). The oldest of anaerobic digestion is the sewage sludge treatment (Mata-alvarez et al., 2014). Biogas is produced from the biochemical breakdown of organic substrates by microorganisms in the absence of oxygen from the anaerobic digestion (Appels et al., 2011; Vergara-Fernández et al., 2008; Brennan and Owende, 2010; Rakmak et al., 2010). Biogas is mainly composed of methane, carbon dioxide and trace gases. Biogas application includes electricity, heating and cooking (Vergara-Fernández et al., 2008). In recent years, research into the potential feedstock for methane yield from anaerobic co-digestion has been conducted. Anaerobic co-digestion is an anaerobic digestion with two or more substrates for improving the economic viability of anaerobic digestion plants due to higher methane production (Mata-Alvarez et al., 2000).

To accelerate the anaerobic digestion, the pretreatment aims to raise the degree of degradation so that the organic substrates can be made better accessible 
for microorganisms (Lier et al., 2001). Pretreatment techniques include thermal, mechanical, biochemical and chemical methods (Lier et al., 2001). Many researchers reported the pretreatment techniques in terms of efficiency, energy balance, environmental sustainability as well as investment, operation and maintenance costs (Mata-Alvarez et al., 2000; Hendriks and Zeeman, 2009; Eggeman and Elanderb, 2005; Carballa et al., 2011; Dereix et al., 2006).

Anaerobic digestion for solid organic wastes is a very promising option because of its ability to transform organic substrates into biogas and its ability to reduce the amount of disposed final solid wastes (Appels et al., 2008). The final solid wastes from anaerobic digestion like fertilizer or soil conditioner. However, the anaerobic digestion for solid organic wastes is often limited by a very long retention time and a low overall degradation efficiency of $30-50 \%$ organic dry solids (Appels et al., 2008). Thus, the pretreatment techniques are required for reducing the time limit factor. Especially, the thermal pretreatment methods are effective at increasing methane production as thermal hydrolysis. Thus, heating the solid fraction of solid organic wastes improved methane production and volatile solids reduction (Mladenovska et al., 2006).

The waste selected for this study is a decanter cake. The decanter cake is a solid organic waste from the palm oil mill industry, containing high organic substrates such as COD and high moisture content. The estimated production and estimated methane production potential of decanter cake is 0.27 million tons/year and 19 million $\mathrm{m}^{3} /$ year, respectively in Thailand (Paepatung et al., 2009). Thus, the biogas potential from decanter cake was estimated to be $16 \mathrm{ktoe}$ and $5.6 \mathrm{MWe}$ of electricity equivalent (Paepatung et al., 2009). Thus, decanter cake can improve the methane production when it is used as co-substrate for anaerobic co-digestion (Kaosol and Sohgrathok, 2012).

Lignocellulose is the major structural material of plant bodies which is a complex structure and also resisting to mechanical stress and enzymatic attack. Pretreatment of fiber to break down its complex structure is an effective way for enhancing anaerobic digestibility. However, it is hard to identify the suitable pretreatment for lignocellulose materials (Hahn-Hägerdal et al., 2006). Bobleter (1994) reported that lignocellulose is heated during thermal pretreatment. Parts of lignocellulose will start to solubilize at above $150-180^{\circ} \mathrm{C}$ (Bobleter, 1994). The thermal pretreatments can be applied to increase the methane yield thus it can improve the biogas production. Microwave, one of the thermal pretreatment techniques, is an electromagnetic radiation with an oscillation frequency for $0.3-300 \mathrm{GHz}$ (Saifuddin and Fazlili, 2009). For cell lyses, the microwave method is very quick and has many potential applications (Sai, 1986). The main objective of this study is to study a methane production enhancement using microwave as a thermal pretreatment for decanter cakes.

\section{Materials and Methods}

Biochemical Methane Potential (BMP) test provides a measure of anaerobic digestibility of organic substrates. BMP test is used to estimate methane yield potential of organic substrates. Organic substrate is tested in a laboratory environment under an optimal condition for microorganism's growth, which is an inexpensive and repeatable method in order to relatively compare the anaerobic digestibility among various substrates (Owen et al., 1979).

\section{Raw Materials and Sample Preparation}

Decanter cake was collected from the palm oil mill industry in Krabi province, Southern of Thailand (Fig. 1). Before using in the experiments, the decanter cake was stored at $4^{\circ} \mathrm{C}$ for stabilization components. The decanter cake characteristics are shown in Table 2. The reported results were the average value of three replicated results together with the standard deviation value. All analytical procedures were performed according to the APHA (1988).

\section{Microwave Pretreatment for Decanter Cake}

The experiments were conducted by varying the heating power and the heating times. The decanter cake $(10 \mathrm{~g})$ was diluted with $50 \mathrm{~mL}$ distilled water in the microwave vessel. The sample was in the slurry form. This homogeneous slurry was shaken. The decanter cake sample was taken to the microwave. The detail operation of microwave was shown in Table 1. When the microwave pretreatment was completed, the pretreated slurry sample was removed from the microwave oven. The sample was cooled to the room temperature. All experiments were run in duplicates. The parameters were analyzed in the pretreated slurry sample such as TCOD, SCOD, PCOD, TS, TDS, TVS and FVS. All analytical procedures were performed in accordance with APHA (1988).

\section{Biochemical Methane Potential (BMP) Test}

Pretreated decanter cake slurry sample $(12 \mathrm{~mL})$ using Microwave was mixed with $48 \mathrm{~mL}$ anaerobic seed. The anaerobic seed was collected from the anaerobic digestion sludge of the palm oil mill wastewater treatment process. The anaerobic seed contains $8.21 \pm 0.06$ of $\mathrm{pH}, 23,916 \pm 522 \mathrm{mg} \mathrm{L}^{-1}$ of TCOD, $2,277 \pm 51 \mathrm{mg} \mathrm{L^{-1 }}$ of SCOD, $4,320 \pm 0 \mathrm{mg} \mathrm{L}^{-1}$ of Alkalinity, $132 \pm 3 \mathrm{mg} \mathrm{L}^{-1}$ of VFA, $31,287 \pm 257 \mathrm{mg} \mathrm{L}^{-1}$ of TS and $18,000 \pm 165 \mathrm{mg} \mathrm{L}^{-1}$ of TVS. The substrate and inoculums ratio was $2: 1 \mathrm{v} / \mathrm{v}$ base on total volatile solids. 
The $\mathrm{pH}$ of mixed sample was adjusted to 7.2 using $\mathrm{HCl}$ or $\mathrm{NaHCO}_{3}$. The mixed slurry sample was placed in serum bottles and flushed with $99.99 \%$ of nitrogen gas for $3 \mathrm{~min}$ to create anaerobic condition before sealing.
The bottles were mixed twice a day by manually shaking the bottles. All reactors were run in duplicates. Two parameters were evaluated including (1) varying heating powers and (2) varying heating times.

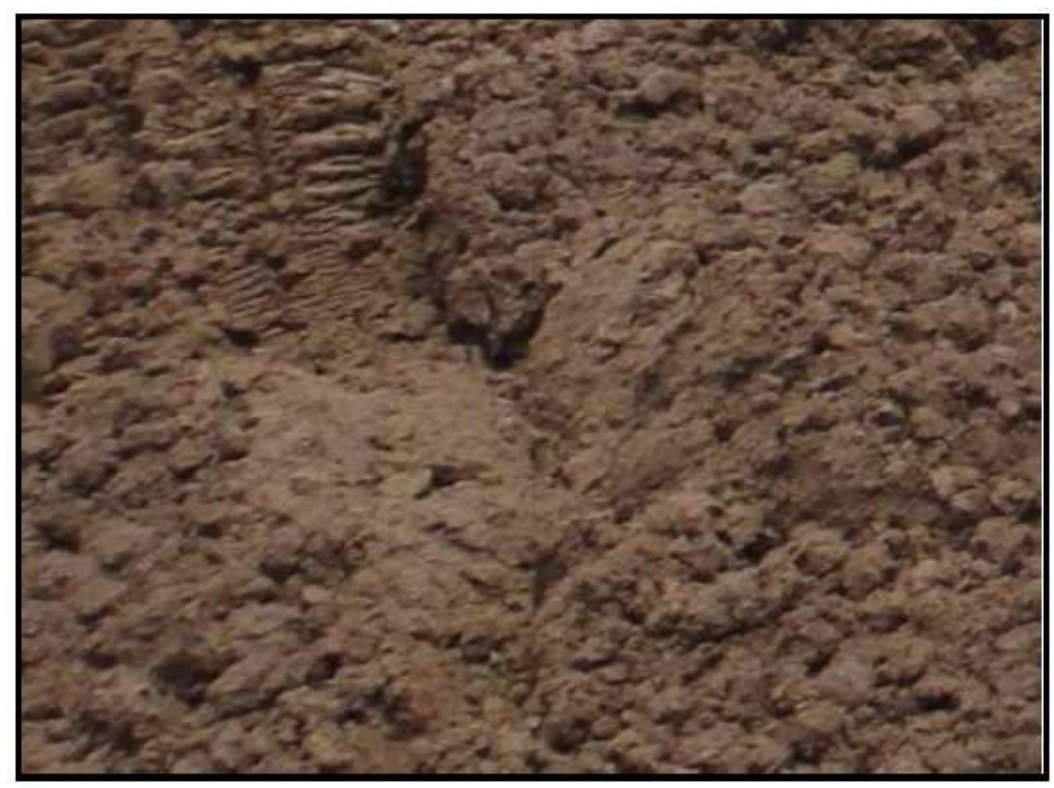

Fig. 1. The decanter cake from palm oil mill factory

Table 1. The detail operation of microwave pretreatment

\begin{tabular}{lll}
\hline Reactor & Power (Watts) & Heating time (min) \\
\hline R1 & - & - \\
R2 & 160 & 2.00 \\
R3 & 160 & 4.00 \\
R4 & 160 & 6.00 \\
R5 & 160 & 8.00 \\
R6 & 320 & 4.00 \\
R7 & 480 & 2.30 \\
R8 & 640 & 2.00 \\
R9 & 800 & 2.30 \\
\hline
\end{tabular}

Table 2. Raw decanter cake characteristics

\begin{tabular}{|c|c|c|}
\hline Parameter & Unit & Decanter cake \\
\hline $\mathrm{pH}$ & - & $4.31 \pm 0.06$ \\
\hline Moisture content & $\%$ & $79.9 \pm 0.6$ \\
\hline Total Solids (TS) & $\%$ & $20.1 \pm 0.6$ \\
\hline Total Volatile Solids (TVS) & $\%$ dry basis & $87.3 \pm 0.4$ \\
\hline Total Dissolved Solids (TDS) & $\%$ dry basis & $20.3 \pm 0.1$ \\
\hline Filtrate Volatile Solids (FVS) & $\%$ dry basis & $15.8 \pm 0.2$ \\
\hline Volatile Fatty Acid (VFA) & $\mathrm{g} / \mathrm{kg}$ dry & $15.0 \pm 0.3$ \\
\hline Total Alkalinity & $\mathrm{g} / \mathrm{kg}$ dry & $5.56 \pm 0.2$ \\
\hline Total Chemical Oxygen Demand (TCOD) & $\mathrm{g} / \mathrm{kg}$ dry & $1,373 \pm 34$ \\
\hline Soluble Chemical Oxygen Demand (SCOD) & $\mathrm{g} / \mathrm{kg}$ dry & $237 \pm 5$ \\
\hline Particulate Chemical Oxygen Demand (PCOD) & $\mathrm{g} / \mathrm{kg}$ dry & $1,136 \pm 15$ \\
\hline Total Kjeldahl Nitrogen (TKN) & $\mathrm{g} / \mathrm{kg}$ dry & $22.5 \pm 0.3$ \\
\hline Ammonia nitrogen $\left(\mathrm{NH}_{3}-\mathrm{N}\right)$ & $\mathrm{g} / \mathrm{kg}$ dry & $0.46 \pm 0.04$ \\
\hline Organic nitrogen (Org-N) & $\mathrm{g} / \mathrm{kg}$ dry & $22.0 \pm 0.1$ \\
\hline Soluble Total Kjeldahl Nitrogen (STKN) & $\mathrm{g} / \mathrm{kg}$ dry & $3.54 \pm 0.083$ \\
\hline
\end{tabular}




\section{Biogas Monitoring}

The daily biogas content is recorded by inserting a gas syringe through the top of the anaerobic digester and letting the biogas displace the wetted barrel of the gas syringe. Biogas content is collected daily. The biogas sample was not collected when the biogas production was less than $5 \%$ of the maximum biogas production. The biogas was analyzed for methane using a Gas Chromatograph (GC) analyzer (GC7890A, Agilent technology, USA) with Thermal Conductivity Detector (TCD).

\section{Calculating the BMP Results}

The daily methane content is analyzed using the calculation of methane percentage from biogas production. The methane yield was calculated based on the proportion of the maximum cumulative methane and removed COD during the anaerobic digestion period, as shown in Equation 1:

$B M P=\frac{\text { max cumulative methane }(\mathrm{ml})}{\text { CODremoved }(\mathrm{g})}$

where, $B M P$ is the methane yield $\left(\mathrm{mL} \mathrm{CH}_{4} / \mathrm{g}\right.$ COD removed); Max cumulative methane is the amount of cumulative methane at the end of the anaerobic digestion period $(\mathrm{mL})$; COD removed is the removed COD at the end of the anaerobic digestion period ( $\mathrm{g}$ COD removed).

\section{Results and Discussion}

\section{Characteristics of Decanter Cake}

The palm oil plant is an important economic plant grown in southern of Thailand. One of organic wastes from the palm oil mill process is decanter cake. The decanter cake is a fibrous material. The characteristics of raw decanter cake are shown in Table 2.

The decanter cake had the high moisture content and total volatile solids. It also had high biodegradability and nutrient-rich contents. The $\mathrm{pH}$ value of decanter cake was low as acidity. After microwave pretreatment of decanter cake, the $\mathrm{pH}$ was adjusted to neutral for starting the methanogenesis. The decanter cake contains high organic substrates in the forms of TCOD, SCOD and PCOD. The ratio of SCOD/TCOD was $17.3 \%$. Thus, the majority of COD was in the form of Particulate COD (PCOD). The decanter cake can be a suitable low cost organic substrate for an anaerobic digestion study.

\section{Effects of Microwave Pretreatment on Decanter} Cake

Table 3 shows the concentrations of COD and solids of decanter cake after the microwave pretreatment process. All the microwave pretreatments release soluble COD and solids (R2R9). The various forms of solids are changed after the microwave pretreatment process. The microwave pretreatment process of decanter cake rises up the TS, TDS, TVS and FVS in all reactors (R2-R9). Total Volatile Solids (TVS) analysis determines the total amount of organic matter in the substrate. Thus, the increasing of TVS can enhance the organic biodegradability and the biogas and methane productions for anaerobic digestion (Prabhudessai et al., 2013).

Microwave pretreatment has proved to be an effective way to break down the structure of fiber and lignocellulosic materials such as rice straw and switch grass (Zhu et al., 2006; Hu and Wen, 2008). The SCOD provides an indication of a general extent of organic carbon solubility. The trends of SCOD, TCOD and PCOD with different heating power and heating times are correlated with the increasing power and heating time. The increasing SCOD can improve the biogas production of anaerobic digestion (Carrère et al., 2008) and reduce the Hydraulic Retention Time (HRT) (Graja et al., 2005).

\section{Effect of Power and Heating Time on BMP test}

Because the microwave pretreatment process of decanter cake induces an improvement of release yields, the biogas and methane production improvements can be expected. Anaerobic digestibility of microwave pretreated decanter cake was evaluated by the Biochemical Methane Potential (BMP) test. Heating power and heating time used in the microwave pretreatment process may influence the microwave pretreatment performance. At the end of the 45-day anaerobic digestion, the characteristics of both nonpretreated and pretreated decanter cake are shown in Table 4. The TS, TDS, TVS and FVS decrease in all reactors. After anaerobic digestion, the organic substrates in the forms of TCOD, SCOD and PCOD reduce significantly in all reactors. The SCOD/TCOD ratio at 160 watts of power and $8 \mathrm{~min}$ of heating time for microwave pretreated decanter cake rises up to $20.4 \%$ in comparison with the SCOD/TCOD ratio of the nonpretreated decanter cake.

Table 5 shows the removal efficiencies of various forms of solids and CODs. On BMP test, the results show no significant removal efficiencies for both non-pretreated decanter cake (R1) and pretreated decanter cake (R2-R9). However, the TS, TVS and FVS removal efficiencies of microwave pretreated decanter cake are slightly higher than that of the non-pretreated decanter cake.

Figure 2 showed the efficiency of TCOD, SCOD, PCOD and FVS removal of non-pretreated decanter cake (R1) and pretreated decanter cake (R2-R9) on BMP tests. Using the microwave pretreatment process of decanter 
Thaniya Kaosol and Worawuth Rungarunanotai / American Journal of Applied Sciences 2016, 13 (5): 609.617 DOI: 10.3844/ajassp.2016.609.617

cake, the removal efficiencies of TCOD, PCOD and FVS are increased. However, the SCOD removal efficiency trends to decrease after the microwave pretreatment process of decanter cake.

Table 3. The chemical characteristics of decanter cake after the microwave pretreatment process

\begin{tabular}{lllllllc}
\hline Reactor & TCOD $(\mathrm{mg} / \mathrm{L})$ & SCOD $(\mathrm{mg} / \mathrm{L})$ & TS $(\mathrm{mg} / \mathrm{L})$ & TDS $(\mathrm{mg} / \mathrm{L})$ & TVS $(\mathrm{mg} / \mathrm{L})$ & FVS $(\mathrm{mg} / \mathrm{L})$ & PCOD $(\mathrm{mg} / \mathrm{L})$ \\
\hline R1 & 27,857 & 3,224 & 33,635 & 8,930 & 22,125 & 3,210 & 24,634 \\
R2 & 28,323 & 3,196 & 33,745 & 8,880 & 22,240 & 3,230 & 25,127 \\
R3 & 28,882 & 3,280 & 33,785 & 8,940 & 22,310 & 3,290 & 25,602 \\
R4 & 28,137 & 3,345 & 34,035 & 9,170 & 22,650 & 3,390 & 24,792 \\
R5 & 29,348 & 3,475 & 34,495 & 8,970 & 23,030 & 3,370 & 25,873 \\
R6 & 30,373 & 3,624 & 35,485 & 9,370 & 23,740 & 3,540 & 26,748 \\
R7 & 30,373 & 3,578 & 35,120 & 9,210 & 23,515 & 3,530 & 26,795 \\
R8 & 30,186 & 3,522 & 34,960 & 9,320 & 23,380 & 3,600 & 26,664 \\
R9 & 29,086 & 3,559 & 34,755 & 9,190 & 23,210 & 3,560 & 25,527 \\
\hline
\end{tabular}

Table 4. The characteristics of non-pretreated and pretreated decanter cakes at the end of BMP test

\begin{tabular}{lllllllc}
\hline Reactor & TCOD $(\mathrm{mg} / \mathrm{L})$ & SCOD $(\mathrm{mg} / \mathrm{L})$ & TS $(\mathrm{mg} / \mathrm{L})$ & TDS $(\mathrm{mg} / \mathrm{L})$ & TVS $(\mathrm{mg} / \mathrm{L})$ & FVS $(\mathrm{mg} / \mathrm{L})$ & PCOD $(\mathrm{mg} / \mathrm{L})$ \\
\hline R1 & 19,322 & 1,453 & 28,010 & 7,780 & 16,585 & 2,060 & 17,869 \\
R2 & 19,661 & 1,559 & 27,780 & 7,900 & 16,490 & 2,020 & 18,102 \\
R3 & 20,056 & 1,542 & 27,950 & 7,900 & 16,600 & 2,045 & 18,515 \\
R4 & 19,887 & 1,536 & 27,725 & 7,850 & 16,510 & 2,150 & 18,351 \\
R5 & 21,356 & 1,559 & 27,985 & 8,050 & 16,625 & 2,075 & 19,797 \\
R6 & 20,650 & 1,609 & 28,405 & 8,180 & 16,950 & 2,110 & 19,041 \\
R7 & 21,017 & 1,592 & 28,625 & 8,035 & 17,070 & 2,130 & 19,425 \\
R8 & 20,650 & 1,620 & 28,345 & 8,060 & 16,855 & 2,145 & 19,303 \\
R9 & 19,718 & 1,598 & 28,125 & 7,960 & 16,745 & 2,205 & 18,120 \\
\hline
\end{tabular}

Table 5. The removal efficiencies of non-pretreated and pretreated decanter cakes at the end of BMP test

\begin{tabular}{llllllll}
\hline Reactor & TCOD (\%) & SCOD (\%) & TS (\%) & TDS (\%) & TVS (\%) & FVS (\%) & PCOD (\%) \\
\hline R1 & 30.6 & 54.9 & 16.7 & 12.9 & 25.0 & 35.8 & 27.5 \\
R2 & 30.6 & 51.2 & 17.7 & 11.0 & 25.9 & 37.5 & 28.0 \\
R3 & 30.6 & 53.0 & 17.3 & 11.6 & 25.6 & 37.8 & 27.7 \\
R4 & 29.3 & 54.1 & 18.5 & 14.4 & 27.1 & 36.6 & 26.0 \\
R5 & 27.2 & 55.1 & 18.9 & 10.3 & 27.8 & 38.4 & 23.5 \\
R6 & 32.0 & 55.6 & 20.0 & 12.7 & 28.6 & 40.4 & 28.8 \\
R7 & 30.8 & 55.5 & 18.5 & 12.8 & 27.4 & 39.7 & 27.5 \\
R8 & 31.6 & 54.0 & 18.9 & 13.5 & 27.9 & 40.4 & 28.6 \\
R9 & 32.2 & 55.1 & 19.1 & 13.4 & 27.9 & 38.1 & 29.0 \\
\hline
\end{tabular}
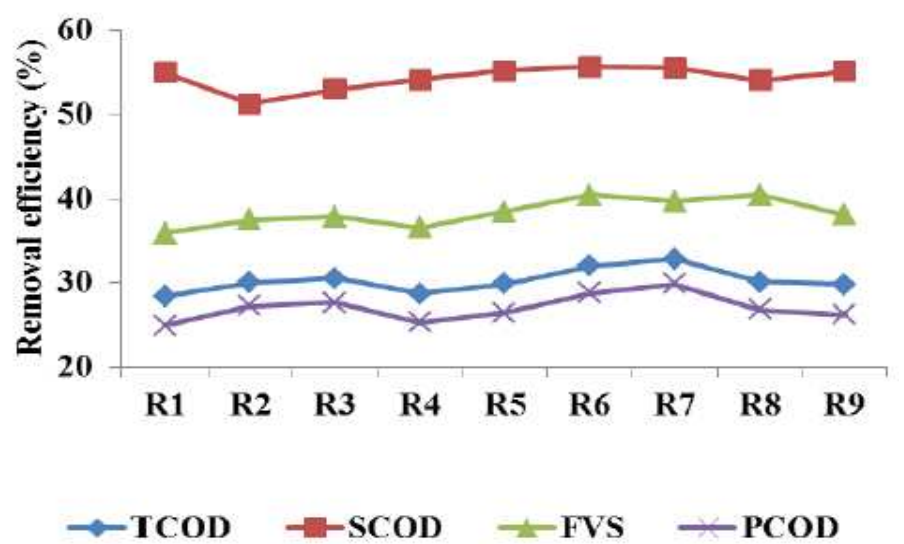

Fig. 2. The removal efficiencies of TCOD, SCOD, PCOD and FVS of non-pretreated and pretreated decanter cakes on BMP test 


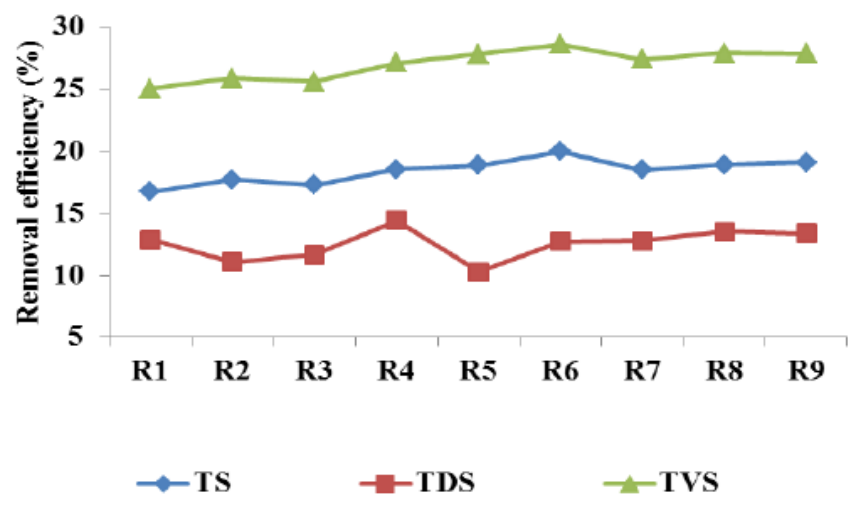

Fig. 3. The removal efficiencies of TS, TDS and TVS of non-pretreated and pretreated decanter cakes on BMP test

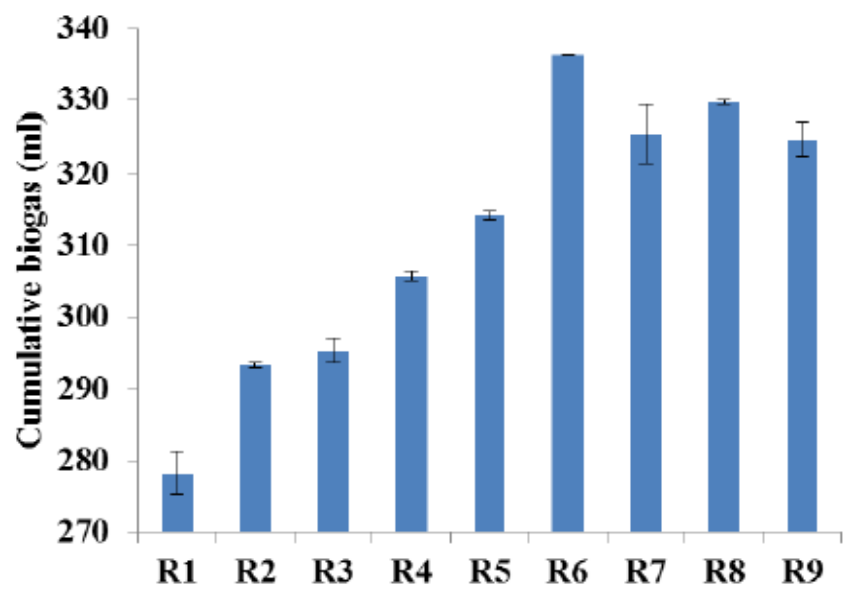

Fig. 4. Cumulative biogas from decanter cake pretreated using microwave pretreatment

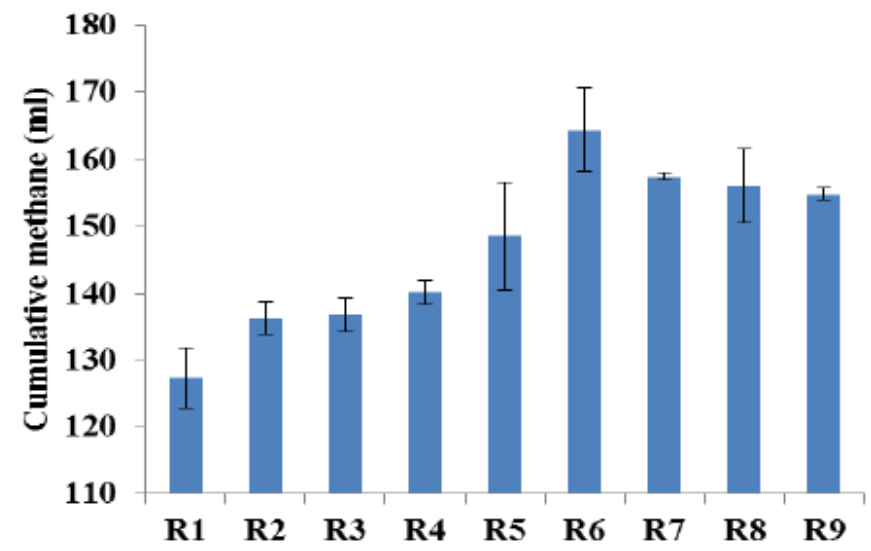

Fig. 5. Cumulative methane from decanter cake pretreated using microwave pretreatment

After the microwave pretreatment process, the TS and TVS removal efficiencies increase in comparison with that of the non-microwave pretreated decanter cake (Fig. 3). The results show that the TVS removal efficiency increases with the increasing of heating time and heating power.
The cumulative biogas from microwave nonpretreated and pretreated decanter cake shows in Fig. 4. As shown in Fig. 4, the microwave pretreated decanter cake has higher amount of cumulative biogas (R2-R9) than that of the non-pretreated decanter cake (R1). The higher cumulative biogas $(293.4-336.3 \mathrm{~mL})$ is achieved 
significantly for the microwave pretreated decanter cake than the cumulative biogas of non-pretreated decanter cake $(278.3 \mathrm{~mL})$. At the same power for microwave pretreatment, increasing of the heating time increases the cumulative biogas (R2-R5). Whereas at the same heating time (comparing between R2 and R8, R3 and R6), increasing the power also increase the cumulative biogas. However, the highest heating power does not provide the highest cumulative biogas because the pretreated decanter cake sample is too hot. The highest cumulative biogas is produced by the reactor containing the decanter cake pretreated with the 360 watts of heating power and 4 min of heating time (R6). The cumulative biogas increases with the increasing total amount of organic matter in the substrate after the microwave pretreatment process (Prabhudessai et al., 2013).

Figure 5 shows the cumulative methane of pretreated decanter cake at the end of the 45-day anaerobic digestion. It also shows that the cumulative methane achieved from the pretreated decanter cake reactors (R2-R9) is higher than that achieved from the non-pretreated decanter cake (R1). The decanter cake pretreated with 360 watts of power and 4 mins of heating time in reactor R6 provides the highest cumulative methane. However, the rate of biogas and methane productions differs significantly according to the operation of microwave pretreatment for decanter cake at various powers and heating times. The cumulative methane also increases with the increasing of the total amount of organic matter in a substrate after microwave pretreatment (Prabhudessai et al., 2013).

The biogas and methane production on BMP test shows in Table 6 . The methane composition of pretreated decanter cake in reactors R2-R9 is ranged between 47.6 and $50.5 \%$. The non-pretreated decanter cake in reactor R1 provides $47.7 \%$ of methane composition. The methane composition of microwave pretreated decanter cake in reactors R2-R9 is higher than that of the non-pretreated decanter cake in reactor $\mathrm{R} 1$ with the exception in the reactor R4. The percentage of methane for these experiments is lower than the typical methane percentage for anaerobic digestion (55-75\% of methane) (Rakmak et al., 2010; Karellas et al., 2010). The maximum methane composition is $50.5 \%$ in reactor R6 that contains the decanter cake with 360 watts of power and 4 min of heating time using microwave pretreatment process.

The methane yield is based on the removed COD during the anaerobic digestion. The methane yield of treated decanter cake in reactors R2-R9 is ranged between 258.4 and $309.9 \mathrm{~mL} \mathrm{CH}_{4} / \mathrm{g}$ COD removed (Table 6). The methane yield of the non-pretreated decanter cake in reactor $\mathrm{R} 1$ is $248.7 \mathrm{~mL} \mathrm{CH} / \mathrm{g}$ COD removed which is the lowest methane yield in this experiment. The theoretical maximum methane production is $350 \quad \mathrm{~mL} \quad \mathrm{CH}_{4} / \mathrm{kg} \quad \mathrm{COD}$ removed (Eskicioglu et al., 2006). Thus, the methane yields of the microwave pretreated decanter cake are lower than the theoretical methane production. At 160 watts of heating power, the biogas production increases with increasing heating time. That is, the methane yield of 258.4, 283.3 and $309.9 \mathrm{~mL} \mathrm{CH}_{4} / \mathrm{g}$ COD removed, are observed from the reactors R3, R4 and R5 which uses 4, 6 and 8 min of heating time, respectively. At 2 min of heating time, the biogas production increases with the increasing power. That is, the methane yield of 262.3 and $272.9 \mathrm{~mL} \mathrm{CH}_{4} / \mathrm{g}$ COD removed, are observed from reactor R2 and R8 which uses 160 and 640 watts of heating power, respectively. The influence of the heating power on the results shows the same trend. At $4 \mathrm{~min}$ of heating time, the biogas production increases with the increasing power. That is, the methane yield of 258.4 and $281.9 \mathrm{~mL}$ $\mathrm{CH}_{4} / \mathrm{g}$ COD removed are observed from reactors $\mathrm{R} 3$ and R6 which uses 160 and 320 watts of heating power, respectively. The decanter cake pretreated with 160 watts of power and $8 \mathrm{~min}$ of heating time, in the reactor R5 provides the highest methane yield. The highest methane yield in reactor $\mathrm{R} 5$ is $309.9 \mathrm{~mL} \mathrm{CH}_{4} / \mathrm{g}$ COD removed. The highest methane yield in this study is near the theoretical methane production of $350 \mathrm{ml} / \mathrm{g}$ COD removed (Eskicioglu et al., 2006) which is provided the confidence in the result based on a COD balance. The microwave pretreatment of decanter cake at 160 watts of heating power and $8 \mathrm{~min}$ of heating time rises up the methane yield to $24.6 \%$ comparing with the nonmicrowave pretreated decanter cake in reactor $\mathrm{R} 1$. The methane production is correlated as the functions of heating power and heating time.

Table 6. The biogas and methane productions of non-pretreated and pretreated decanter cakes on BMP test

\begin{tabular}{lllll}
\hline Reactor & Biogas $(\mathrm{mL})$ & Methane $(\mathrm{mL})$ & Methane $(\%)$ & $\begin{array}{l}\text { Methane yield }(\mathrm{mL} \\
\left.\mathrm{CH}_{4} / \mathrm{g} \text { COD removed }\right)\end{array}$ \\
\hline R1 & 278.3 & 132.7 & 47.7 & 248.7 \\
R2 & 293.4 & 141.7 & 48.3 & 262.3 \\
R3 & 295.4 & 142.2 & 48.1 & 258.4 \\
R4 & 305.7 & 145.6 & 47.6 & 283.3 \\
R5 & 314.3 & 154.0 & 49.0 & 309.9 \\
R6 & 336.3 & 169.8 & 50.5 & 281.9 \\
R7 & 325.4 & 162.9 & 50.1 & 280.7 \\
R8 & 329.8 & 161.5 & 49.0 & 272.9 \\
R9 & 324.8 & 160.2 & 49.3 & 275.6 \\
\hline
\end{tabular}


In conclusion, the limitation of decanter cake is its slow organic degradation under the anaerobic digestion. Microwave pretreatment process is capable of improving the decanter cake biodegradability by increasing the organic solubility fraction or Soluble Chemical Oxygen Demand (SCOD).

\section{Conclusion}

Decanter cake solubilization process is the ratelimiting step for the anaerobic digestion. Microwave pretreatment is the thermal pretreatment method. The microwave pretreatment of decanter cake is applied to enhance the solubilization of decanter cake. The aim of this study is to optimize the methane yield using microwave pretreatment. The two parameters in this study are the heating power and the heating time. The study uses the BMP tests. The results show that the decanter cake structure is destroyed by the microwave pretreatment process. Microwave pretreatment of decanter cake enhances the COD solubilization. The increasing of heating power and heating time for microwave pretreatment process of decanter cake can improve the biogas production and the methane yield. The maximum methane yield is achieved in reactor R5 at 160 watts of heating power and $8 \mathrm{~min}$ of heating time for microwave pretreatment process. The least methane yield is $248.7 \mathrm{~mL} \mathrm{CH}_{4} / \mathrm{g}$ COD removed which is observed from reactor R1 (non-microwave pretreatment). The highest methane yield is $309.9 \mathrm{~mL}$ $\mathrm{CH}_{4} / \mathrm{g}$ COD removed. The microwave pretreatment of decanter cake at 160 watts of heating power and $8 \mathrm{~min}$ of heating time can improve the methane yield to $24.6 \%$ comparing with the non-microwave pretreatment of decanter cake.

The results can be concluded that the heating power and heating time used in microwave pretreatment are optimized. The optimal values of heating power and heating time are 160 watts and $8 \mathrm{~min}$ for the best methane yield. The results obtained in this study show that the microwave pretreatment is beneficial to the solubility of the complex decanter cake particles.

\section{Acknowledgement}

Authors gratefully acknowledge Prince of Songkla University for financial support of this study (Fund no. ENG540661S).

\section{Author's Contributions}

Thaniya Kaosol: Designed the research plan, organized the study and contributed to the writing of the manuscript.

Worawuth Rungarunanotai: Participated in all experiments and contributed to the writing of the manuscript.

\section{Ethics}

This work is original and presents unpublished material. All authors have examined and agreed the manuscript. We confirm that no ethical issues concerned.

\section{References}

APHA, 1988. Standard Method for the Examination of Water and Wastewater. 1st Edn., American Public Health Association, ISBN-10: 0875530788, pp: 161.

Appels, L., J. Baeyens, J. Degreve and R. Dewil, 2008. Principles and potential of the anaerobic digestion of waste-activated sludge. Progress Energy Combust. Sci., 34: 755-781. DOI: 10.1016/j.pecs.2008.06.002

Appels, L., J. Lauwers, J. Degreve, L. Helsen and B. Lievens et al., 2011. Anaerobic digestion in global bio-energy production: Potential and research challenges. Renewable Sustainable Energy Rev., 15: 4295-4301.

Bobleter, O., 1994. Hydrothermal degradation of polymers derived from plants. Progress Polymer Sci., 19: 797-841. DOI:10.1016/0079-6700(94)90033-7.

Brennan, L. and P. Owende, 2010. Biofuels from microalgae-a review of technologies for production, processing and extractions of biofuels and coproducts. Renewable Sustainable Energy Rev., 14: 557-577. DOI: 10.1016/j.rser.2009.10.009

Carballa, M., C. Duran and A. Hospido, 2011. Should we pretreat solid waste prior to anaerobic digestion? An assessment of its environmental cost. Environ. Sci. Technol., 45: 10306-10314. DOI: $10.1021 / \mathrm{es} 201866 \mathrm{u}$

Carrère, H., C. Bougrier, D. Castets and J.P. Delgenès, 2008. Impact of initial biodegradability on sludge anaerobic digestion enhancement by thermal pretreatment. J. Environ. Sci. Health A, 43: 15511555. DOI: $10.1080 / 10934520802293735$

Dereix, M., W. Parker and K. Kennedy, 2006. Steamexplosion pretreatment for enhancing anaerobic digestion of municipal wastewater sludge. Water Environ. Res., 78: 474-485. DOI: $10.2175 / 106143006$ X95456

Eggeman, T. and R.T. Elanderb, 2005. Process and economic analysis of pretreatment technologies. Bioresource Technol., 96: 2019-2025. DOI: 10.1016/j.biortech.2005.01.017

Eskicioglu, C., K.J. Kennedy and R.L. Droste, 2006. Characterization of soluble organic matter of waste activated sludge before and after thermal pretreatment. Water Res., 40: 3725-3736. DOI: $10.1016 /$ j.watres.2006.08.017

Graja, S., J. Chauzy, P. Fernandes, L. Patria and D. Cretenot, 2005. Reduction of sludge production from WWTP using thermal pretreatment and enhanced anaerobic methanisation. Water Sci. Technol., 52: 267-273. 
Hahn-Hägerdal, B., M. Galbe, M.F. Gorwa-Grauslund, G. Lidén and G. Zacchi, 2006. Bio-ethanol-the fuel of tomorrow from the residues of today. Trends Biotechnol., 24: 549-556.

DOI: 10.1016/j.tibtech.2006.10.004

Hendriks, A.T.W.M. and G. Zeeman, 2009. Pretreatments to enhance the digestibility of lignocellulosic biomass: A review. Bioresource Technol., 100: 10-18. DOI: 10.1016/j.biortech.2008.05.027

$\mathrm{Hu}$, Z.H. and Z.Y. Wen, 2008. Enhancing enzymatic digestibility of switchgrass by microwave-assisted alkali pretreatment. Biochem. Eng. J., 38: 369-378. DOI: $10.1016 /$ j.bej.2007.08.001

Kaosol, T. and N. Sohgrathok, 2012. Enhancement of biogas production potential for anaerobic codigestion of wastewater using decanter cake. Am. J. Agric. Biol. Sci., 7: 494-502. DOI: 10.3844/ajabssp.2012.494.502

Karellas, S., I. Boukis and G. Kontopoulos, 2010. Development of an investment decision tool for biogas production from agricultural waste. Renewable Sustainable Energy Rev., 14: 1273-1282. DOI: 10.1016/jrser.2009.12.002

Lier, J.B., A. Tilche, B.H. Ahring, R. Moletta and M. Dohanyos et al., 2001. New perspectives in anaerobic digestion. Water Sci. Technol., 43: 1-18. DOI: $10.1016 /$ j.ces.2004.07.070

Malakahmad, A., S. Nasrudin and N.E. Ahmad Basri, 2012. Biomethanation of kitchen waste and sewage sludge in anaerobic baffled reactor. Proceedings of the IEEE Symposium on Humanities, Science and Engineering Research, Jun. 24-27, IEEE Xplore Press, Kuala Lumpur, pp: 1513-1516. DOI: 10.1109/SHUSER.2012.6268835

Malakahmad, A., S. Nasrudin, N. Ahmad Basri and S.M. Zain, 2013. Anaerobic transformation of biodegradable waste; simultaneous production of energy and fertilizer. Am. J. Environ. Sci., 9: 113-119. DOI: 10.3844/ajessp.2013.113.119

Mata-Alvarez, J., J. Dosta, M.S. Romero-Guiza, X. Fonoll and M. Peces et al., 2014. A critical review on anaerobic co-digestion achievements between 20102013. Renewable Sustainable Energy Rev., 36: 412-427. DOI: 10.1016/j.rser.2014.04.039

Mata-Alvarez, J., S. Macé and P. Llabrés, 2000. Anaerobic digestion of organic solid wastes. An overview of research achievements and perspectives. Bioresource Technol., 74: 3-16. DOI: 10.1016/S0960-8524(00)00023-7
Mladenovska, Z., H. Hartmann, T. Kvist, M. Sales-Cruz and R. Gani et al., 2006. Thermal pretreatment of the solid fraction of manure: Impact on the biogas reactor performance and microbial community. Water Sci. Technol., 53: 59-67. DOI: $10.2166 /$ wst.2006.236

Owen, W.F., D.C. Stuckey, J.B. Healy Jr., L.Y. Young and P.L. McCarty, 1979. Bioassay for monitoring biochemical methane potential and anaerobic toxicity. Water Res., 13: 485-492. DOI: 10.1016/0043-1354(79)90043-5

Paepatung, N., A. Nopharatana and W. Songkasiri, 2009. Bio-methane potential of biological solid materials and agricultural wastes. Asian J. Energy Environ., 10: 19-27.

Prabhudessai, V., A. Ganguly and S. Mutnuri, 2013. Biochemical methane potential of agro wastes. J. Energy, 2013: 350731-350737. DOI: $10.1155 / 2013 / 350731$

Rakmak, N., W. Wiyaratn and J. Chungsiriporn, 2010. Removal of $\mathrm{H} 2 \mathrm{~S}$ from biogas by iron $(\mathrm{Fe} 3+)$ doped $\mathrm{MgO}$ on ceramic honeycomb catalyst using double packed columns system. Eng. J., 14: 15-24. DOI: $10.4186 /$ ej.2010.14.1.15

Sai, T.S., 1986. A microwave method for the extraction of cellular ATP. J. Biochem. Bioph. Meth., 13: 343-345. DOI: 10.1016/0165-022X(86)90041-2.

Saifuddin, N. and S.A. Fazlili, 2009. Effect of microwave and ultrasonic pretreatments on biogas production from anaerobic digestion of palm oil mill effluent. Am. J. Eng. Applied Sci., 2: 139-146. DOI: 10.3844/ajeassp.2009.139.146

Vergara-Fernández, A., G. Vargas, N. Alarcón and A. Velasco, 2008. Evaluation of marine algae as a source of biogas in a two-stage anaerobic reactor system. Biomass Bioenergy, 32: 338-344. DOI:10.1016/j.biombioe.2007.10.005.

Zhu, S.D., Y.X. Wu, Z.N. Yu, X. Zhang, H. Li and M. Gao, 2006. The effect of microwave irradiation on enzymatic hydrolysis of rice straw. Bioresource Technol., 97: 1964-1968.

DOI: $10.1016 /$ j.biortech.2005.08.008 